\title{
Urgences
}

\section{Rocaille d'octobre}

\section{Robert Paquin et Raymond Chamberlain}

Numéro 16, mars 1987

D.G. Jones : d'un texte, d'autres

URI : https://id.erudit.org/iderudit/025401ar

DOI : https://doi.org/10.7202/025401ar

Aller au sommaire du numéro

Éditeur(s)

Urgences

ISSN

0226-9554 (imprimé)

1927-3924 (numérique)

Découvrir la revue

Citer ce document

Paquin, R. \& Chamberlain, R. (1987). Rocaille d'octobre. Urgences, (16), 76-77. https://doi.org/10.7202/025401ar d'utilisation que vous pouvez consulter en ligne.

https://apropos.erudit.org/fr/usagers/politique-dutilisation/ 


\section{Robert Paquin ROCAILLE D'OCTOBRE}

Sous la bruine, ces ruines

d'ombres sont

un tombeau de fleurs

Sont un bouquet aux couleurs

de feuilles mortes où

les cailloux fleurissent

comme un bouquet de tomes

que les trépassés

se repassent

Ma bouche déborde

de cailloux colorés

et les carcasses de mes collègues

ressemblent à des fleurs

Est-ce la jungle, le paradis

d'Angkor Wat

ou le centre-ville

la nuit? Il n'y a là

ni vie ni mort.

ni rien d'humain. Ce que je longe

sombre, sous la bruine, c'est

une excroissance de runes 
ROCK GARDEN: OCTOBER is a deceptively simple poem requiring - like all real poetry - close reading. Not the solemn attentiveness of scalpel-wielding critics seeking scalps but the celebratory reading of one who enjoys a poem enough to memorize it or to translate it, to try to make it mean in another language. Robert Paquin has succeeded in celebrating Doug Jones's poem in a related but nonetheless distant language. There is some loss - Jones's brilliant use of "runes» defies full translation into French. But his almost casual stroll past his stones, with its unexpected observations and reflections that lead to poetry, are beautifully conveyed by Paquin in a poetic transposition that honours the poet. This should be evident to anyone who can sing or, at the very least, hum in the two languages.

\section{Raymond Chamberlain}

